\title{
EFFECT OF FEED RAW MATERIALS TYPES ON DISSOLVED PROTEIN CONTENT, PROTEIN HYDROLYSIS LEVEL AND FEED NUTRITION CONTENT OF ORANGE MANGROVE CRAB (Scylla olivacea) LARVAE FEED
}

\author{
Haryati*, Yushinta Fujaya, Edison Saade \\ Fakultas Ilmu Kelautan dan Perikanan Universitas Hasanuddin \\ * haryati_fikpunhas@yahoo.com
}

\begin{abstract}
Feed is one of the factors that affect the success of hatchery culture of mud crab (Scylla olivacea). The use of artificial feed in the form of microdiet can ensure availability, lower production costs and higher flexibility than natural feed. During this time the artificial feed used is a commercial feed, which is relatively expensive, therefore the need for research to produce artificial feed of good quality, with a cheap price.. The objective of this research is to determine the combination of raw material of artificial feed protein which produce dissolved protein content, protein hydrolysis degree and best protein content of feed. The experimental design used was completely randomized with eight treatments and three replications. The treatments were the use of various combinations of feed protein ingredients : A) $100 \%$ Artemia flour, B) $100 \%$ fish meal, C) $100 \%$ squid meal, D) $50 \%$ Artemia and 50\% fish meals, E) 50\% Artemia and 50\% squid meals, F) 50\% fish and 50\% squid meals, G) 35\% fish, 35\% squid and 30\% Artemia meals, H) commercial feed. The parameters used were dissolved protein content, protein hydrolysis degree and protein feed content. The results showed that the difference of feed protein raw materials had significant effect $(p<0,05)$ on soluble protein content and feed protein hydrolysis degree. The highest content of soluble protein in in the diet with a protein raw material was squid meal, but not significantly different $(\mathrm{P}>0,05)$ than Artemia meal and combination between 50\% Artemia and 50\% squid meals, but significantly different ( $\mathrm{P}<$ $0.05)$ than other treatments. The highest degree of protein hydrolysis in the diet with a protein raw materials was Artemia meal, but not significantly different $(\mathrm{P}>0.05)$ than in commercial feed as well as combination between Artemia and squid meal ( $\mathrm{P}>0.05)$, but significantly different $(\mathrm{P}<0,05)$ compared to other treatments. Feed protein content according to the needs of mangrove crab larvae. Fat content with a protein raw materials was $100 \%$ artemia meal was higher than the need. Carbohydrate content with a protein raw materials were $100 \%$ artemia meal, a combination of $50 \%$ artemia meal and 50\% squid meal and commercial feed according to the needs of mud crab larvae.
\end{abstract}

Keywords: protein raw materials, protein hydrolysis degree, protein feed content, dissolved protein content

\section{PENDAHULUAN}

Pakan adalah merupakan salah satu faktor penentu keberhasilan usaha pembenihan biota perairan. Penggunaan pakan buatan dalam bentuk mikro (microdiet) dapat menjamin ketersediaan, biaya produksi lebih rendah dan fleksibilitasnya lebih tinggi (Gatesoupe dan Luquet, 1991). Haryati et al. (2015) telah melakukan penelitian pengaruh penggantian pakan alami dengan pakan buatan di mana pakan yang digunakan adalah pakan komersial, hasil penelitian tersebut menunjukkan bahwa pada pemeliharaan larva kepiting bakau mulai stadia zoea 1 sampai megalopa, pakan buatan baru dapat diberikan mulai stadia zoea 3. Penggunaan pakan buatan dalam pemeliharaan larva 
dapat dipercepat dengan melakukan predigest pakan yang akan digunakan. Hasil penelitian Haryati et al. (2018) menunjukkan bahwa larva kepiting bakau (Scylla olivacea) dapat diberi pakan buatan yang sudah dipredigest dengan penambahan enzim papain dengan konsentrasi $4,5 \%$ pada pakan buatan mulai stadia zoea 2.

Penggunaan pakan buatan komersial harga relatif mahal, yaitu Rp. 250 000,- per $\mathrm{kg}$, oleh karena itu perlu dilakukan penelitian untuk mengembangkan pakan buatan yang mempunyai kualitas sesuai dengan kebutuhan larva dengan harga yang lebih murah dibandingkan pakan buatan komersial. Microbound diets adalah salah satu jenis pakan buatan yang secara luas diaplikasikan pada studi nutrisi larva krustase. Kualitas microbound diets ditentukan oleh bahan baku sumber protein (May-Hellen, 2008). Bahan baku protein akan berpengaruh terhadap kualitas pakan. Tujuan dari penelitian ini adalah menentukan kombinasi bahan baku sumber protein pakan buatan setelah dihidrolisa dengan menggunakan enzim papain yang menghasilkan kandungan protein terlarut, derajat hidrolisis protein dan kualitas pakan yang terbaik, serta membandingkan pakan tersebut dengan pakan komersial

\section{METODE PENELITIAN}

Proses pembuatan pakan dan hidrolisis pakan dilakukan di laboratorium nutrisi dan teknologi pakan, Fakultas Ilmu Kelautan dan perikanan UNHAS. Analisis kandungan protein terlarut, derajat hidrolisis protein dan analisis proksimat pakan di lakukan di laboratorium Kimia Makanan Ternak Fakultas Peternakan Universitas Hasanuddin. Analisis komposisi asam amino dan asam lemak pakan dilakukan di Laboratorium Terpadu IPB.

Enzim papain yang digunakan adalah Newzime yang diproduksi oleh Balai
Budidaya Air Payau (BBAP) Jepara. Pakan buatan yang digunakan adalah pakan komersial berbentuk bubuk.

Untuk menganalisis pengaruh perbedaan bahan baku protein pakan terhadap kadar protein terlarut dan derajat hidrolisis protein digunakan rancangan acak lengkap dengan 8 perlakuan dan 3 kali ulangan. Perlakuan dalam penelitian ini yaitu:
A. $100 \%$ tepung Artemia
B. $100 \%$ tepung ikan
C. $100 \%$ tepung cumi
D. $50 \%$ tepung Artemia, $50 \%$ tepung ikan
E. $50 \%$ tepung Artemia, 50\% tepung cumi
F. $50 \%$ tepung ikan, $50 \%$ tepung cumi
G. $30 \%$ tepung Artemia, 35\% tepung ikan, $35 \%$ tepung cumi
H. Pakan komersial

Selain bahan baku protein ditambahkan 5\% minyak ikan, $5 \%$ vitamin mineral mix dan $5 \%$ tepung tapioka sebagai bahan pengikat. Pakan dihidrolisa dengan menggunakan enzim papain $4,5 \%$

Analisis kadar protein terlarut dan derajat hidrolisis protein dilakukan secara invitro. Ditimbang $10 \mathrm{~g}$ pakan yang akan dipredigest, ke dalam pakan tersebut selanjutnya ditambahkan enzim papain $4,5 \%$ yang sebelumnya telah diencerkan dengan $1 \mathrm{ml}$ aquades. Campuran tersebut selanjutnya diinkubasikan selama 120 menit. Setelah inkubasi selesai, sampel pakan diambil sebanyak $0,5 \mathrm{~g}$ dan dihentikan reaksi hidrolisis proteinnya dengan menambahkan 1,5 ml larutan trikloroasetat $7 \%$ dan dibiarkan pada suhu ruang. Selanjutnya ditambah $3 \mathrm{ml}$ Tris $\mathrm{HCl} \mathrm{pH}$ 6,5 dan disentrifuse dengan kecepatan $10000 \mathrm{rpm}$ selama 20 menit. Supernatan yang diperoleh digunakan untuk analisis kadar protein terlarut mengikuti metode Bradford. Endapan yang dihasilkan digunaan untuk analisis kadar protein total dengan menggunakan metode 
Kjeldahl. Derajat hidrolisis protein pakan dihitung dengan menggunakan rumus:

$\mathrm{DHP}=\frac{\mathrm{P}_{0}-\mathrm{P}_{\mathrm{t}}}{\mathrm{Po}} \times 100$

Dimana:

DHP = derajat hidrolisis protein

Po = kadar protein pakan sebelum dihidrolisis

$\mathrm{P}_{\mathrm{t}} \quad=$ kandungan protein pakan setelah hidrolisis dalam jangka waktu

Selain parameter tersebut juga dilakukan analisis prosimat, komposisi asam amino dan asam lemak pakan untuk mengevaluasi kualitas pakan yang dihasilkan.

Untuk mengetahui pengaruh perbedaan bahan baku protein pakan serta pakan komersial terhadap kandungan protein terlarut dan derajat hidrolisis protein digunakan analisis ragam (ANOVA). Apabila perlakuan berpengaruh nyata dilanjutkan dengan uji W-Tukey untuk menentukan bahan baku protein pakan yang menghasilkan kandungan protein terlarut dan derajat hidrolisis protein terbaik. Untuk mengetahui pengaruh perbedaan bahan baku protein pakan maupun pakan komersial terhadap kualitas pakan berdasarkan hasil analisis proksimat, komposisi asam amino dan asam lemak dianalisis secara diskriptif sesuai kebutuhan larva kepiting bakau.

\section{HASIL DAN PEMBAHASAN}

Kandungan protein terlarut dan derajat hidrolisis protein pakan, pada berbagai bahan baku protein pakan serta pakan komersial setelah dihidrolisa dengan menggunakan enzim papain 4,5\% disajikan pada Tabel 1. Hasil analisis ragam menunjukkan bahwa perbedaan bahan baku protein pakan maupun pakan komersial berpengaruh nyata $(\mathrm{P}<0,05)$ terhadap kandungan protein terlarut maupun derajat hidrolisis protein. Kandungan protein terlarut paling rendah pada pakan komersial tetapi tidak berbeda nyata $(\mathrm{P}>0,05)$ dibandingkan pakan dengan bahan baku protein $100 \%$ tepung ikan serta kombinasi $50 \%$ tepung ikan dan 50\% tepung cumi. Kandungan protein terlarut paling tinggi pada pakan dengan sumber protein $100 \%$ tepung cumi-cumi, tetapi tidak berbeda nyata $(\mathrm{P}>0,05)$ dibandingkan pakan dengan sumber protein $100 \%$ tepung Artemia maupun kombinasi antara 50\% tepung Artemia dan 50\% tepung cumi, tetapi berbeda nyata $(\mathrm{P}<0,05)$ dibandingkan perlakuan lainnya.

Derajat hidrolsis protein paling tinggi pada pakan dengan bahan baku protein tepung Artemia tetapi tidak berbeda nyata $(\mathrm{P}>0.05)$ dibandingkan pada pakan komersial maupun kombinasi antara tepung Artemia dan tepung cumi $(\mathrm{P}>0,05)$, tetapi berbeda nyata $(\mathrm{P}<0,05)$ dibandingkan perlakuan lainnya.

Hidrolisis protein adalah proses pemecahan ikatan kovalen yang menghubungkan asam-asam amino penyusun protein. Pada proses hidrolisis, ikatan kovalen antar molekul akan terputus dan akan dihasilkan asam amino bebas (Zayas, 1997). Faktor faktor yang mempengaruhi proses hidrolisis meliputi rasio enzim dan substrat, perbedaan jenis enzim, pH, waktu dan suhu hidrolisis. Rasio antara enzim dan substrat berbanding lurus dengan derajat hidrolisa (Dumay et al. 2006). Peningkatan enzim protease meningkatkan jumlah nitrogen terlarut dari hidrolisat selama proses hidrolisis (Wang et al. 2007). Menurut Kirk dan Othmer (1985), selama hidrolisis terjadi konversi protein yang bersifat tidak larut menjadi senyawa nitrogen yang bersifat larut, selanjutnya terurai menjadi senyawasenyawa yang lebih sederhana, seperti peptida-peptida, asam amino dan amonia. Tingginya kandungan protein terlarut dan derajat hidrolisis protein pada pakan 
dengan bahan baku protein $100 \%$ tepung Artemia karena pada pakan tersebut konsentrasi enzim lebih tinggi dibandingkan perlakuan lainnya. Selain enzim papain yang digunakan untuk menghidrolisa pakan, pada Artemia juga terdapat enzim protease yang akan menghidrolisa protein. Menurut Nielsen (1997) semakin besar konsentrasi protease akan semakin banyak ikatan peptida dari protein yang terputus menjadi peptidapeptida sederhana sehingga kelarutan protein semakin meningkat. Hal ini sesuai pendapat Haslaniza et al. (2010) yang menyatakan bahwa konsentrasi enzim proteolitik yang semakin meningkat dalam proses hidrolisis akan menyebabkan peningkatan kandungan nitrogen terlarut dalam hidrolisat protein ikan.

Tabel 1. Rata-rata Kandungan protein terlarut (\%) dan derajat hidrolisis protein (\%) pakan pada berbagai bahan baku protein setelah dihidrolisis dengan enzim papain

\begin{tabular}{|l|r|c|}
\hline \multicolumn{1}{|c|}{ Perlakuan } & Protein terlarut & Derajat hidrolisis Protein \\
\hline A - 100\% tepung Artemia & $2,43^{\mathrm{ab}} \pm 0,062$ & $65,40^{\mathrm{a}} \pm 0,3906$ \\
B - 100\% tepung ikan & $1,98^{\mathrm{cd}} \pm 0,016$ & $48,45^{\mathrm{c}} \pm 0,2949$ \\
C - 100\% tepung cumi & $2,76^{\mathrm{a}} \pm 0,031$ & $53,70^{\mathrm{b}} \pm 1,4985$ \\
D - 50\% tepung Artemia, 50\% tepung ikan & $2,33^{\mathrm{b}} \pm 0,011$ & $53,04^{\mathrm{b}} \pm 0,5773$ \\
E- 50\% tepung Artemia, 50\% tepung cumi & $2,41^{\mathrm{ab}} \pm 0,003$ & $63,57^{\mathrm{a}} \pm 1,1139$ \\
F - 50\% tepung ikan, 50\% tepung cumi & $2,19^{\mathrm{cd}} \pm 0,009$ & $47,20^{\mathrm{c}} \pm 0,0882$ \\
G- 30\% tepung Artemia, 35\% tepung ikan, & $2,22^{\mathrm{bc}} \pm 0,123$ & $54,17^{\mathrm{b}} \pm 0,3906$ \\
& & \\
H - Pakan komersial & $1,82^{\mathrm{d}} \pm 0,004$ & $64,30^{\mathrm{a}} \pm 0,3354$ \\
\hline
\end{tabular}

Keterangan: Huruf yang sama pada kolom yang sama menunjukkan tidak berbeda nyata pada taraf $5 \%$

Tingginya kandungan protein terlarut pada pakan dengan $100 \%$ tepung cumi karena kandungan protein pakan relatif tinggi sehingga substrat yang dihidrolisa juga tinggi, sedangkan pada pakan dengan bahan baku protein $50 \%$ tepung Artemia dan $50 \%$ tepung cumi disebabkan pengaruh kombinasi, yaitu suplai enzim protease yang berasal dari tepung Artemia dan tingginya kandungan protein pada cumi- cumi. Tingginya derajat hidrolisis protein pada pakan komersial karena kandungan protein relatif rendah sehingga enzim dapat menghidrolisa pakan dengan baik. Hal ini sesuai pendapat Dumay et al. (2006) bahwa rasio antara enzim dan substrat berbanding lurus dengan derajat hidrolisa.

Hasil analisis proksimat pakan pada berbagai bahan baku protein serta pakan komersial disajikan pada Tabel 2.

Tabel 2. Hasil analisis proksimat pakan (\% bobot kering)

\begin{tabular}{cccccc}
\hline Perlakuan & Protein & Lemak kasar & Serat kasar & BETN & Abu \\
\hline A & 55.22 & 18.02 & 1.15 & 11,19 & 14.42 \\
B & 52.16 & 12.61 & 1.16 & 4.79 & 29.28 \\
C & 81.21 & 11.10 & 0.84 & 1,43 & 5.42 \\
D & 54.62 & 13.46 & 0.93 & 9,04 & 21,95 \\
E & 67.00 & 12.97 & 1.27 & 10,26 & 8,5 \\
F & 65.77 & 10.90 & 0.71 & 5.09 & 17.51 \\
G & 78.32 & 11.33 & 0.70 & 4.75 & 4.90 \\
H & 47.70 & 3.49 & 2.16 & 27.81 & 18.82 \\
\hline
\end{tabular}

Keberhasilan pemberian pakan ditentukan oleh kualitas dan kuantitas pakan yang diberikan. Kualitas pakan secara kimiawi antara lain ditentukan oleh 
kandungan protein, lemak dan karbohidrat. Kebutuhan protein pada Scylla serrata stadia megalopa menurut Genodepa et al. (2004) adalah 79,4\%, sedangkan menurut Catacutan (2002) kebutuhan protein juvenil Scylla serrata berkisar antara 34,2\%$51,8 \%$. Kandungan protein pakan berkisar antara 47,70\% - 81.21\%. Berdasarkan kandungan protein, pakan dengan bahan baku protein $100 \%$ tepung cumi lebih tinggi dari kebutuhan, sedangkan pakan dengan bahan baku protein yang lain serta pakan komersial mempunyai kualitas sesuai kebutuhan larva kepiting bakau.

Lemak diketahui mempunyai peran penting sebagai sumber enersi, menjaga integritas struktur membrane biologi dan berfungsi sebagai precursors steroid penting (Corraze et al, 2001) Pengaruh kandungan lemak pakan terhadap pertumbuhan juvenil kepiting bakau telah diteliti oleh Sheen dan Wu (1999), hasil penelitian menunjukkan bahwa kandungan lemak pakan berkisar antara 3,3\% sampai $13,8 \%$ memenuhi kebutuhan kepiting bakau. Catacutan (2002), mengemukakan bahwa kebutuhan lemak dari juveniles Scyllla serrata berkisar antara $6 \%$ sampai $12 \%$. Kebutuhan lemak Scylla serrata stadia megalopa sebesar 6\% (Genodepa et al., 2004). Kandungan lemak pakan berkisar antara 3,49\% - 18,02\%. Kandungan lemak pakan komersial lebih rendah dibandingkan kebutuhan larva kepiting bakau, sedangkan pakan dengan bahan baku protein $100 \%$ tepung Artemia kandungan lemaknya lebih tinggi dari kebutuhan. Kandungan lemak pakan dengan bahan baku protein yang lain masih sesuai kebutuhan larva kepiting bakau.

Kandungan BETN pakan berkisar antara $1,43 \%-27,81 \%$ bahan kering. Sheen dan Wu (1999) dan Sheen (2000) mengemukakan bahwa kebutuhan karbohidrat juvenil Scylla serrata berkisar antara $13,5 \%$ sampai $27 \%$ bahan kering.
Kebutuhan karbohidrat pada larva kepiting bakau belum diketahui. Berdasarkan pendapat tersebut kandungan karbohidrat pakan dengan bahan baku $100 \%$ tepung Artemia, kombinasi antara 50\% tepung Artemia dan 50\% tepung cumi serta pakan komersial berturut-turut 12,31\%, 11,32\% dan $27,81 \%$ bahan kering relatif sesuai kebutuhan larva kepiting bakau. Kandungan karbohidrat pakan yang tersusun atas beberapa bahan baku protein yang lain perlu ditingkatkan.

\section{KESIMPULAN DAN SARAN}

1. Kandungan protein terlarut pada pakan dengan bahan baku protein 100\% tepung cumi, $100 \%$ tepung Artemia dan kombinasi antara 50\% tepung Artemia dan 50\% tepung cumi lebih tinggi dibandingkan pakan komersial maupun bahan baku protein pakan yang lain

2. Derajat hidrolisis protein pada pakan dengan bahan baku protein pakan $100 \%$ tepung Artemia dan $100 \%$ tepung cumi dan pakan komersial relatif sama tetapi lebih tinggi dibandingkan bahan baku ptotein yang lain.

3. Kandungan protein pakan dengan bahan baku protein $100 \%$ tepung cumi lebih tinggi dari kebutuhan, sedangkan bahn baku protein yang lain serta pakan komersial sesuai dengan kebutuhan larva kepiting bakau. Kandungan lemak dengan bahan baku protein $100 \%$ tepung Artemia lebih tinggi dari kebutuhan. Kandungan karbohidrat pakan dengan bahan baku $100 \%$ tepung Artemia, kombinasi antara 50\% tepung Artemia dan 50\% tepung cumi serta pakan komersial sesuai kebutuhan larva kepiting bakau.

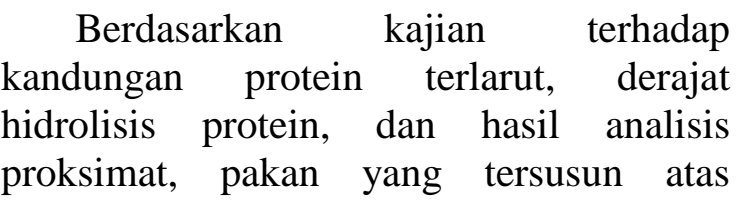


berbagai baku protein dapat menggantikan pakan komersial.

\section{UCAPAN TERIMA KASIH}

Ucapan terima kasih ditujukan kepada Kementerian Ristek dan Perguruan Tinggi yang telah membiayai penelitian ini melalui Penelitian Terapan Unggulan Perguruan Tinggi Terapan untuk anggaran tahun 2018.

\section{DAFTAR PUSTAKA}

1. Catacutan, M. R., 2002. Growth and body composition of juvenile mud crab, Scylla serrata, fed different dietary protein and lipid levels and protein to energy ratio. Aquaculture, 208: $113-123$

2. Corraze, C., 2001. Lipid nutrition. In: Gillume, J., Kaushik, S., Begot., Metailler, R. (Eds.),

3. Nutrition and feeding of fish and crustacean. Praxix, Chshester, U.K, pp. 111 -129.

4. Dumay J, Donnay-Moreno C, Barnathan G, Jaouen \& P, Berge. 2006. Improvement of lipid and phospholipid recoveries from sardine (Sardina pilchardus) viscera using industrial proteases. Process Biochem 41:2327-2332.DOI: 10.1016/j.procbio.2006.04.005

5. Gatesoupe, F. \& P. Luquet, 1991. Practical diet for mass culture of the rotifer Brachionus plicatilis: application to larval rearing of sea bass, Dicentrarchus labrax. Aquaculture, 22; 149 163

6. Genodepa, J., P.C. Southgate \& C. Zeng, 2004. Preliminary assessment of amicrobound diet as an Artemia replacement for mud crab, Scylla serrata megalopa. Aquaculture, 236: 497 - 509.

7. Haryati, Y. Fujaya \& Anugrah. 2015. Pengaruh pergantian pakan alami dengan pakan buatan terhadap aktivitas enzim pencernaan kepiting bakau (Scylla olivacea). Prosiding Seminar Nasional Perikanan dan Kelautan XII UGM, jilid I Budidaya Perikanan, hal: 137 - 144 .

8. Haryati, Y. Fujaya \& E. Saade, 2018. Effect of Using Papain Enzyme in Artificial Diet on the Degree of Protein Hydrolysis and Protease Enzyme Activity of Mud Crab (Scylla olivacea) Larva. Aquacultura Indonesiana Vol. 19(2) : 82.(http://aquasiana.org/index.php/ai/article/view/118/121)

9. Haslaniza, H. 2010. The effects of enzyme concentration, temperature and incubation time on content and degree of hydrolysis of protein precipitate from cockle (Anadara granosa) meat wash water. International Food Research Journal 17: 147-152

10. Kirk, R.E. \& D.F.Othmer, 1985. “ Encyclopedia of Chemical Technology “,vol.1, 3rd edition, A Willey Interscience Publication, John Wiley and Sons Co., New York.

11. May-Helen, H, 2008. Towards development of formulated diet for mud crab (Scylla serrata) larvae, with emphasis on lipid nutrition. PhD thesis, James Cook University. 190 pp.

12. Nielsen PM, 1997. Food Proteins and Their Applications. Marcel Dekker, Inc. New York.

13. Sheen, S.S. \& S.W. Wu, 1999. The effect of dietary lipid levels on the growth response of juvenile mud crab, Scylla serrata. Aquaculture, 93: 121 - 134

14. Sheen, S.S., 2000. Dietary cholesterol requirement of juvenile mud crab Scylla serrata. Aquaculture, 189: $277-285$

15. Wang J.S., M.M. Zhao,Q.Z. Zhao, Y. Bao \& Y.M. Jiang. 2007. Characterization of hydrolysates derived from enzymatic hydrolysis of wheat gluten. J Food Sci72: C103-C107. DOI: 10.1111/j.1750-3841.2006.00247.x.

16. Zayas, J.F. 1997. Fungtional Properties of Protein in Food. Springer-Verlag. Berlin 